\title{
Impact of Quercetin, Diallyl Disulfide and Nimbolide on the Regulation of Nuclear Factor Kappa B Expression in Prostate and Breast Cancer Cell Lines
}

\author{
Arunakaran J*, Arunkumar R, Elumalai P and Senthilkumar K \\ Department of Endocrinology, Dr. ALM Post Graduate Institute of Basic Medical Sciences, University of Madras, Chennai, India
}

\begin{abstract}
NFKB is a key regulator of genes involved in cell activation and proliferation. Activation of NFKB has been implicated in prostate and breast cancer development and growth. Quercetin, a flavonoid from onion, diallyl disulfide (DADS) an organosulfur compound from garlic and nimbolide, a tetranortriterpenoid from neem leaf have been shown to anticancer activities in various cancers. All the above compounds decreased the prostate and breast cancer cell viability. The IC-50 value of PC-3 cells of Quercetin was $100 \mu \mathrm{M}$; DADS was $40 \mu \mathrm{M}$ and IC-50 value of breast cancer cells such as MCF-7, MDA-MB-231 cells were $4 \mu \mathrm{M}$ and $6 \mu \mathrm{M}$, respectively. Therefore, for further studies 50 and $100 \mu \mathrm{M}$ quercetin, 20 and $40 \mu \mathrm{M}$ DADS, were selected for prostate cancer treatment. 2 and $4 \mu \mathrm{M} / \mathrm{ml}$ nimbolide concentrations for MCF-7 cells and 4 and $6 \mu \mathrm{M} / \mathrm{ml}$ for MDA-MB-231 breast cancer cells were considered for further study. PC-3 cells were treated with quercetin/DADS; MCF-7/MDA-MB-231 cells were treated with nimbolide. NFKB protein expression was studied by western blot. Protein expressions of IKKa and IKK $\beta$ were also studied on DADS treated PC-3 cell line and nimbolide treated both breast cancer cell lines by western blot. Protein expression of IKKa and IKK $\beta$ were also studied on DADS treated PC-3 cell line and nimbolide treated both breast cancer cell lines by western blot. Quercetin/DADS decreased the expression of NFKB on PC-3 cells. DADS significantly decreased IKKa, IKK $\beta$ and NFKB expressions on PC-3 cells. Nimbolide also significantly decreased the protein expressions of IKKa, IKK $\beta$ and NFKB in both breast cancer cell lines. Therefore, the present investigation showed down regulation of nuclear factor kappa B factor expression in androgen independent prostate cancer cells by quercetin or DADS. Nimbolide also did the same on estrogen positive and negative breast cancer cell lines. The data will be discussed with Akt and MAPK signaling regulation on prostate and breast cancer cell lines.
\end{abstract}

Keywords: Quercetin; Nimbolide; Nuclear transcription factor kappa B (NFкB)

\section{Introduction}

Nuclear transcription factor kappa $\mathrm{B}(\mathrm{NF \kappa B})$ is a ubiquitous and evolutionarily conserved transcription factor that is activated in response to a number of carcinogens and inflammatory stimuli including cytokines, tumor promotors, and cigarette smoke, environmental pollutants, ionizing radiation and stress. In resting cells, NFkB is kept in an inactive state in the cytoplasm as a hetero trimer consisting of $\mathrm{p} 50$, p65 and I $\kappa \beta$ proteins including IKK $\alpha, \operatorname{IKK} \beta$ and IKB $\varepsilon$ [1]. In response to activation signals, the IKB $\alpha$ subunit is phosphorylated at serine residues 32 and 36 and ubiquitinated at lysine residues 21 and 22 which target them for proteosome mediated degradation. The p65 subunit is then phosphorylated and translocated to the nucleus where it binds to a specific DNA sequence and activation the transcription of over 500 genes involved in immunoregulation, growth regulation, inflammation, carcinogenesis and apoptosis. The phosphorylation of $\mathrm{I} \kappa \mathrm{B} \alpha$ is catalyzed by IKBa kinase (IKK) which consists of three subunits, IKKa, IKK $\beta$, IKKe (also called NEMO). Some natural plant derivatives have been reported to inhibit $\mathrm{NF \kappa B}$ activation through modification of a specific cysteine residue $\left(\mathrm{Cys}^{179}\right)$ in the activation loop of IKK $\beta$ [2-4].

$\mathrm{PI} 3 \mathrm{~K}$ is involved in a variety of cellular functions, including cell growth, proliferation, differentiation, motility, survival, intracellular trafficking and in prevention of cell death $[5,6]$. PI3Ks constitute a lipid kinase family characterized by their ability to phosphorylate inositol ring 3'-OH group in inositol phospholipids. Class-I PI3Ks are heterodimers composed of a catalytic subunit (p110) and an adaptor/ regulatory subunit (p85). PI3K is activated by growth factors, which in turn phosphorylates phosphatidyl inositol $(3,4)$-bisphosphate (P2) to form phosphatidyl inositol $(3,4,5)$-trisphosphate (P3), the latter anchors Akt/Protein Kinase B (PKB) to the plasma membrane by binding to its Plecstrin Homology (PH) domain [7]. Activated Akt dissociates from membrane and phosphorylates a number of proteins leading to regulation of metabolism (via glycogen synthase kinase-3
(GSK-3), GLUT4), translational control (via p70 S6 kinase and PHAS1), and cell survival (via NFkB, fork head family transcription factors, BAD and caspase 9) [8].

Quercetin (3,3' $4^{\prime} 5-7$ penta hydroxyl flavanone) is a principle flavonoid compound of onions, apple, etc and it possesses a wide spectrum of pharmacological properties. Quercetin inhibits cell growth and induces apoptosis in various cancer cells [9-16]. Quercetin enhances TRAIL induced apoptosis in prostate cancer cells via increased protein stability of death receptor [14].

Diallyl disulfide (DADS) a major organosulfur compound derived from garlic has been shown to decrease the formation of carcinogen induced cancers and to inhibit the proliferation of various cancer cells [17]. The mechanism of action of DADS is associated with activation of metabolizing enzymes, suppression of the formation of DNA adducts, antioxidants, regulation of cell cycle arrest, induction of apoptosis and differentiation, histone modification and inhibition of angiogenesis and invasion.

Nimbolide, a tetranortriterpenoid isolated from the leaves and flowers of neem tree has attracted recent research interest due to its anti proliferative and apoptosis inducing effects on a panel of cancer

*Corresponding author: Arunakaran J, Department of Endocrinology, Dr. ALM Post Graduate Institute of Basic Medical Sciences, University of Madras Chennai-600113, India, E-mail: j_arunakaran@hotmail.com

Received September 16, 2013; Accepted September 26, 2013; Published September 30, 2013

Citation: Arunakaran J, Arunkumar R, Elumalai P, Senthilkumar K (2013) Impact of Quercetin, Diallyl Disulfide and Nimbolide on the Regulation of Nuclear Factor Kappa B Expression in Prostate and Breast Cancer Cell Lines. Nat Prod Chem Res 1: 115 doi:10.4172/ 2329-6836.1000115

Copyright: @ 2013 Arunakaran J, et al. This is an open-access article distributed under the terms of the Creative Commons Attribution License, which permits unrestricted use, distribution, and reproduction in any medium, provided the original author and source are credited. 
cells $[18,19]$. Recent studies demonstrated that nimbolide exerts potent anticancer effects in HepG2 cells by abrogating NFkB activation and its downstream events such as activation of wnt $/ \beta$-catenin pathway and apoptosis evasion [20].

The present aim is to investigate the role of quercetin, DADS and nimbolide on the regulation of NFKB expression which is a key regulator of gene involved in cell activation and proliferation. We studied on both prostate and breast cancer cell lines, separately.

\section{Materials and Methods}

Dulbecco's modified Eagle's medium (DMEM), DADS, Quercetin and the monoclonal $\beta$-actin antibody were purchased from Sigma Chemical Pvt Ltd, USA. Polyclonal antibodies against NFkB were obtained from Santa Cruz Biotechnology (Santa Cruz, CA, USA). Nimbolide (Purity 98\%) was purchased from Asthagiri Research Foundation, India. Polyvinylidinedifluoride (PVDF) membrane was purchased from Millipore, USA. Trypsin-EDTA, Fetal Bovine Serum (FBS), antibiotics-antimycotics, and Phosphate Buffered Saline (PBS) were purchased from Gibco, Canada. The secondary antibodies, Horse Radish Peroxidase (HRP) conjugated rabbit-anti mouse IgG and goatanti rabbit IgG were obtained from Genei, Bangalore, India. Enhanced Chemi Luminescence (ECL) kit was procured from Thermo scientific, USA. All other chemicals were purchased from SRL chemicals, India.

\section{Cell line and culture}

PC-3 cell line, Estrogen dependent (MCF-7) and Estrogen independent (MDA-MB-231) breast cancer cell lines were obtained from the NCCS, Pune. The PC-3 cells were grown in RPMI-1640 medium supplemented with $10 \%$ Fetal Bovine Serum (FBS-Gibco, Invitrogen) and maintained in humidified incubator at $37^{\circ} \mathrm{C}$ with $5 \%$ $\mathrm{CO}_{2}$. Breast cancer cells were grown in T25 culture flasks containing DMEM supplemented with $10 \%$ FBS and $1 \%$ antibiotics $(100 \mu \mathrm{g} / \mathrm{ml}$ penicillin and $100 \mu \mathrm{g} / \mathrm{ml}$ streptomycin) upon reaching confluency, the cells were trypsinized and passaged.

\section{Quercetin, DADS and Nimbolide preparation}

They were prepared separately by dissolving the dimethyl sulfoxide (DMSO) to prepare $1 \mathrm{mM}$ stock solution. From the stock they were prepared at different micro molar concentration with serum free medium. In all the preparation the concentration of DMSO never exceeded $0.01 \%$.

\section{Cell viability}

Viable cell either PC-3/MCF/MDA MB 231 cells were measured by a colorimetric assay composed by solution of a tetrazolium compound MTT (dimethythiazolyltetrazolium bromide). MTT is bio reacted by cell into a formazon product that is soluble and the absorbance of the formazan at $570 \mathrm{~nm}$ is measured directly. Cells were seeded at a density of $5 \times 10^{3}$ cells/well in a 96 well plate and incubated at $24 \mathrm{~h}$ at $37^{\circ} \mathrm{C}$ in $5 \% \mathrm{CO}_{2}$. After attachment the cells were washed with PBS and then Serum Free Medium (SFM) was added for 6-12 h. The cells were added into fresh medium containing different concentrations of quercetin/DADS/Nimbolide in the respective experiments and allowed to grow for an additional 24 and $48 \mathrm{~h}$ after respective treatment. The medium was removed and washed twice with PBS and $100 \mu \mathrm{l}$ of 0.5 $\mathrm{mg} / \mathrm{ml} \mathrm{MTT} \mathrm{solution} \mathrm{was} \mathrm{added} \mathrm{to} \mathrm{each} \mathrm{well} \mathrm{and} \mathrm{incubated} \mathrm{for} \mathrm{2-3} \mathrm{h}$. After incubation $100 \mu \mathrm{l}$ of DMSO was added for solubilization of cells and then kept in dark for $1 \mathrm{~h}$. The intensity of the color developed was read at $570 \mathrm{~nm}$ in an ELISA reader. The cell viability was calculated as follows.

$$
\frac{\text { Absorbance of treated cells }}{\text { Absorbance of control cells }} \times 100
$$

Triplicate measurements with different quercetin/DADS/nimbolide concentrations were performed and the concentrations that gave a 50\% reduction in a number of living cells $\left(\mathrm{IC}_{50}\right)$ were estimated.

\section{Western blot analysis}

After $24 \mathrm{~h}$ treatment period the cells were lysed in RIPA buffer containing $1 \%$ protease inhibitor cocktail and protein concentrations were determined by Lowry et al. [21]. Cell lysate $(50 \mu \mathrm{g})$ were electrophoresed in $12 \%$ SDS polyacrylamide gel and then transferred into PVDF membranes. The membranes were incubated with primary antibodies against PI3K, pAkt, Akt, IKKa, IKK $\beta$, NFkB (1:1000) in tri buffered saline. After washing the membranes were incubated with HRP conjuagated anti-mouse IgG (1:5000) or HRP conjugated Goat-anti-rabbit IgG (1:5000). Protein bands were detected using chemiluminensence system (ECL kit) and quantified in chemi-Doc XRS Imaging system, Bio rad (USA).

\section{Statistical anlaysis}

The data were analyzed using the SPSS windows students' version software. For all the measurement, one way ANOVA followed by Student Newman-Keuls' test was used to assess the statistical significance of difference between control and drugs treated. A statistically significant difference was considered at the level of $\mathrm{p}<0.05$.

\section{Results}

\section{Effect of quercetin on cell viability of PC-3 cell line}

To investigate the effect of quercetin induced viability, the human prostate cancer PC3 cells were treated with various concentrations (25$125 \mu \mathrm{M})$ of quercetin. Quercetin decreased the cell viability gradually increased the cell viability gradually increased concentration of quercetin. At $48 \mathrm{~h}, 100 \mu \mathrm{M}$ concentration of quercetin treatment showed $50 \%$ of viable cells. From these results the $\mathrm{IC}_{50}$ value of quercetin was calculated as $100 \mu \mathrm{m}$ concentration. 50 and $100 \mu \mathrm{M}$ concentration of quercetin doses were selected (Figure 1).

\section{Effect of DADS on cell viability of PC-3 cell line}

$50 \%$ inhibition was found in $40 \mu \mathrm{m}$ and hence for western blot we selected 20 and $40 \mu \mathrm{M}$ to identify the effect DADS in signaling molecules (Figure 2).

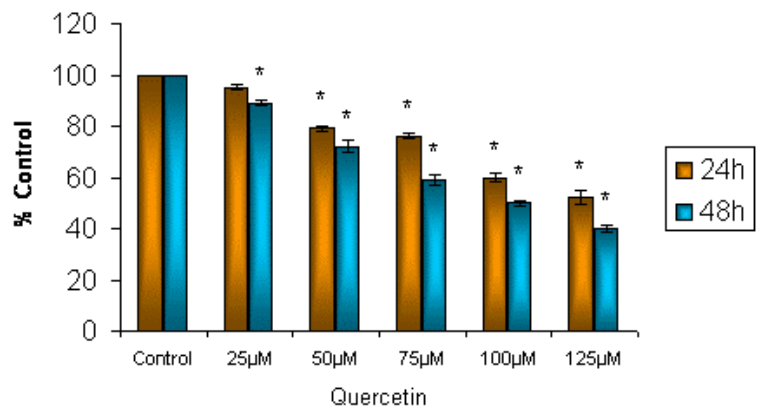

Each bar represents the mean \pm SEM of six independent observations.

'*'represents statistical significance between control Vs quercetin treatment groups at $p<0.05$ level using Student's-Newman-Keul's test.

Figure 1: Effect of quercetin on PC-3 cell viability. 


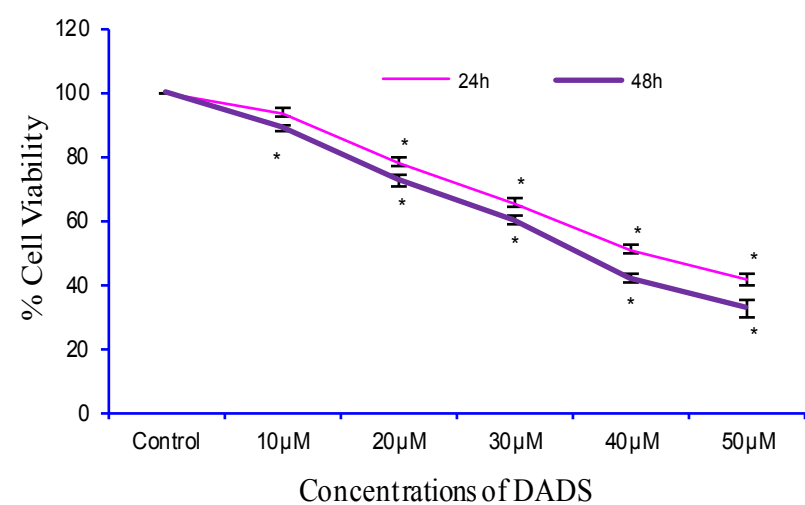

Each bar represents the mean \pm SEM of six independent observations. “*'represents statistical significance between control versus DADS treatment groups at $p<0.05$ level using Student's-Newman-Keul's test.

Figure 2: Effects of DADS on PC-3 cell viability for 24 and $48 \mathrm{~h}$.
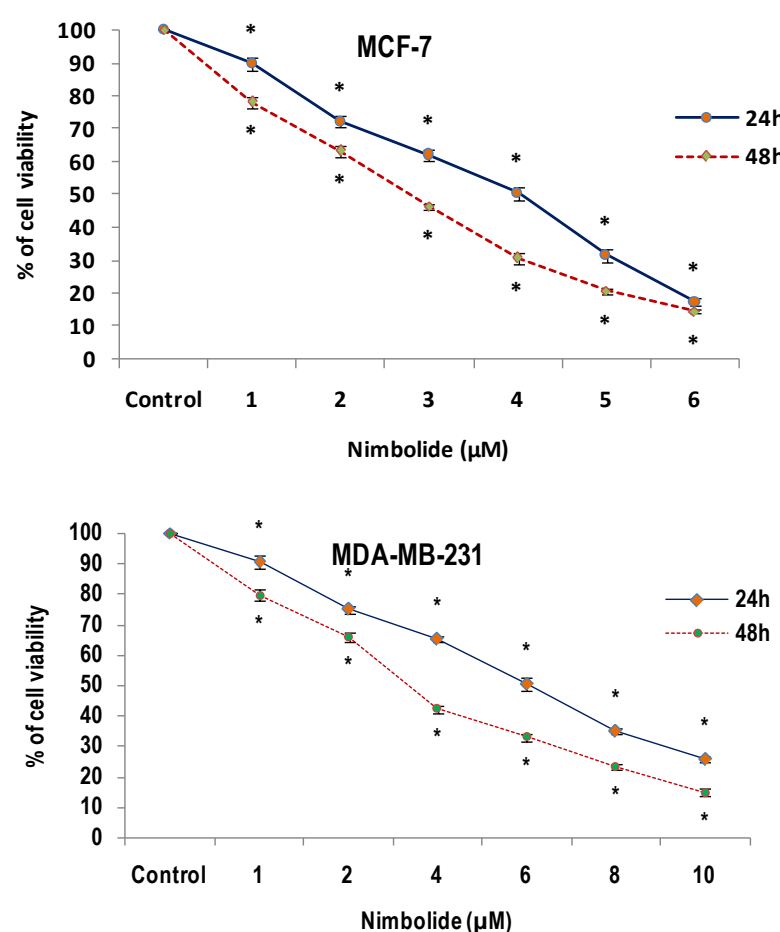

Each bar represents the mean \pm SEM of six independent observations.

'*'represents statistical significance between control versus nimbolide treatment groups at

$p<0.05$ level using Student's-Newman-Keul's test.

Figure 3: Effect of nimbolide on cell viability of MCF-7 and MDA-MB-231 cell lines.

\section{Effect of nimbolide on cell viability of MCF 7 and MDA MB} 231 cell line

Nimbolide significantly decreased the viability of both the cells (MCF 7) (Figure 3) and MDA-MB 231 cells (Figure 4) at $24 \mathrm{~h}$ with $\mathrm{IC}_{50}$ values of $4 \mu \mathrm{M} / \mathrm{ml}$ and $4 \mu \mathrm{M} / \mathrm{ml}$ respectively. Hence, 2 and $4 \mu \mathrm{M} / \mathrm{ml}$ concentrations for MCF7 cells and 4 and $6 \mu \mathrm{M} / \mathrm{ml}$ concentrations for MDA-MB 231 cells were considered for western blot studies (Figure 3).

\section{Effect of quercetin on protein levels of PI3K and p-Akt}

Protein levels of PI3K and p-Akt were assessed by western blot analysis. PI3K decreased after quercetin treatment in PC-3 cells (Figure 4). Akt is a cell survival protein. Phosphorylation of serine 473 of Akt was decreased significantly but not totals Akt. So, p-Akt was normalized with total Akt (Figure 4).

\section{Effect of quercetin on protein levels of NFкB in PC3 cells}

$\mathrm{NF \kappa B}$ is involved in cell survival and proliferation of prostate cancer cells assessed by western blot analysis. In our present study, quercetin decreases NFKB (Figure 5). Thereby quercetin inhibits cell survival and proliferation of PC3 cells (Figure 5).

\section{Effect of DADS on protein levels of PI3K and pAkt}

Protein levels of PI3K and pAkt were assessed by western blot analysis. PI3K decreased after DADS treatment in PC-3 cells (Figure 6). Akt is a cell survival protein. Phosphorylation of serine 473 of Akt was decreased significantly but not totals Akt. So, pAkt was normalized with total Akt (Figure 6)
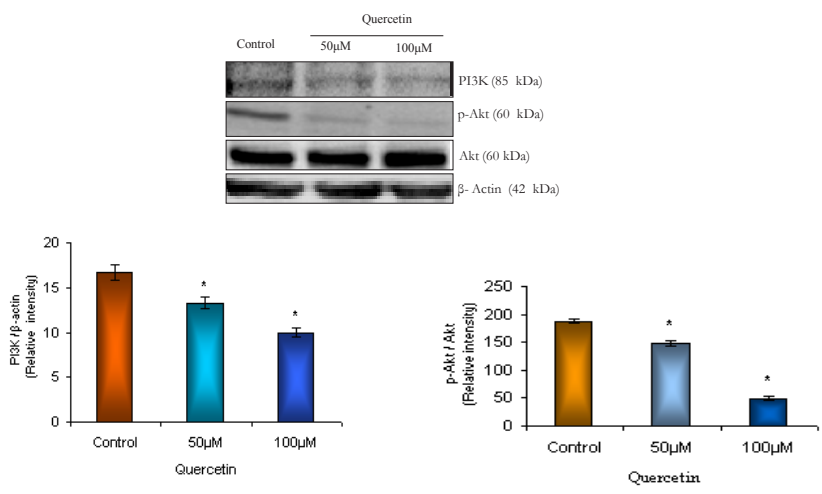

Each bar represents the mean \pm SEM of three independent observations.

'*' represents statistical significance between control Vs quercetin treatment groups at $p<0.05$ level using Student's-Newman-Keul's test.

Figure 4: Effects of quercetin on PI3K,p-Akt, Akt, Cyclin D1 protein expression in PC-3 cells.
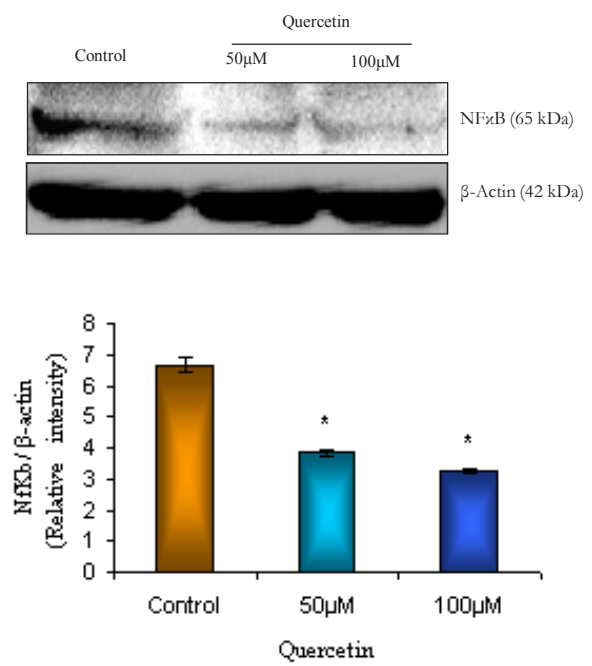

Each bar represents the mean \pm SEM of three independent observations. '*'represents statistical significance between control Vs quercetin treatment groups at $p<0.05$ level using Student's-Newman-Keul's test.

Figure 5: Effect of quercetin on NfKB and $\beta$-Catenin protein expression in $\mathrm{PC}-3$ cells. 


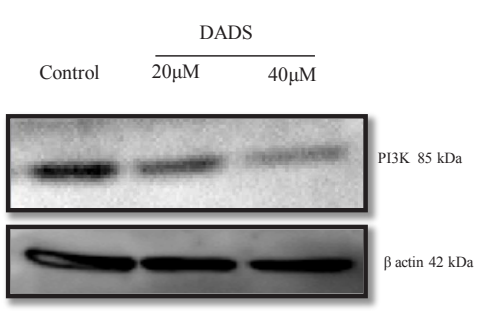

Control $\quad \frac{\text { DADS }}{20 \mu \mathrm{M} \quad 40 \mu \mathrm{M}}$
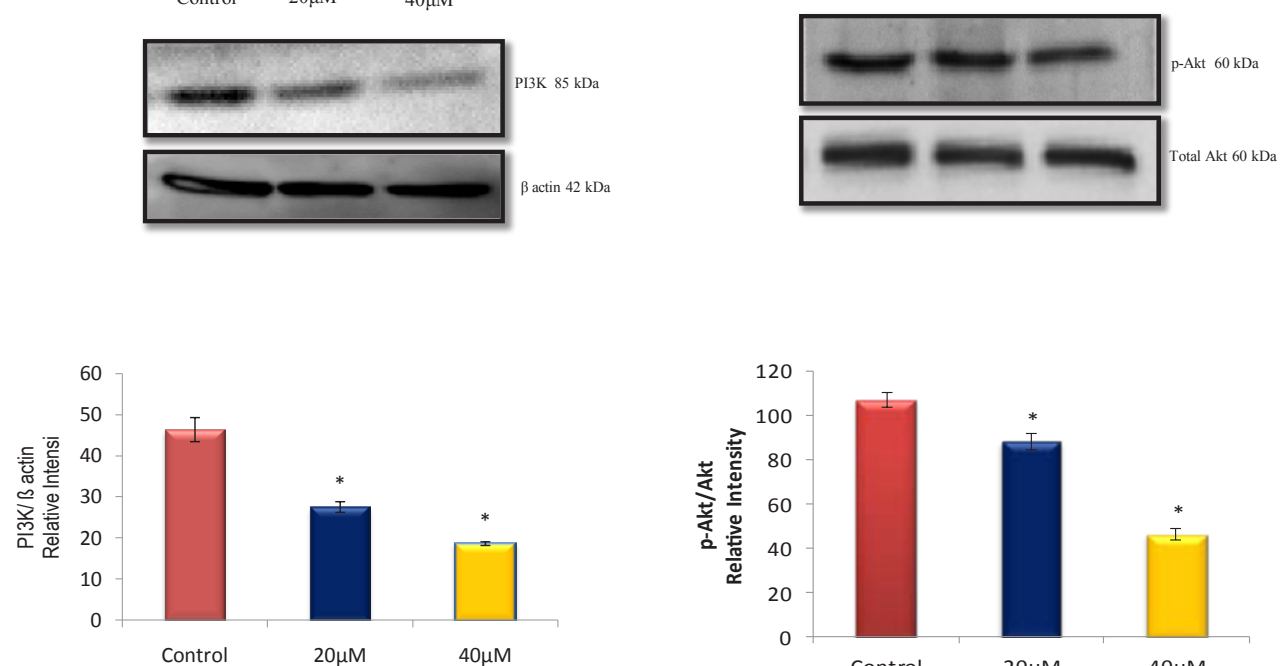

Protein expressions were analyzed by western blotting. Each bar represents the mean \pm SEM of three independent observations. '*'represents statistical significance between control versus DADS treatment groups at $p<0.05$ level using Student's-Newman-Keul's test. L1- control; L2- $20 \mu \mathrm{M}$ DADS; L3- $40 \mu \mathrm{M}$ DADS

Figure 6: Effect of DADS on PI3K, p-Akt and Total Akt protein expression in PC-3 cells.
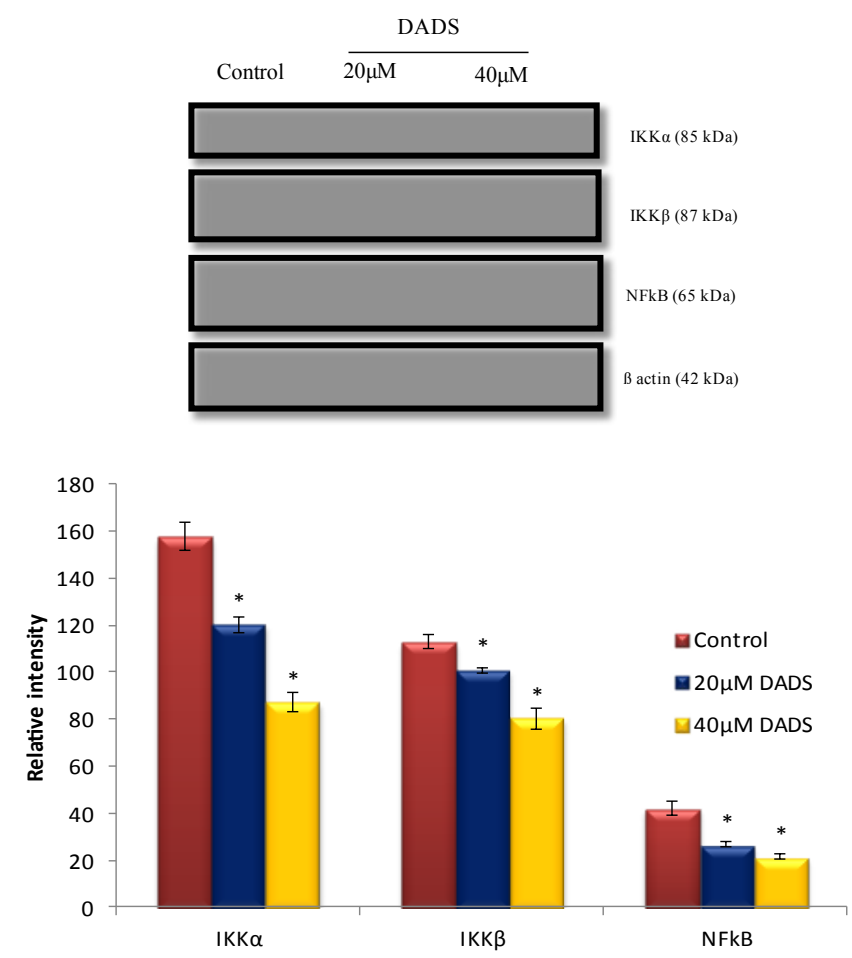

Protein expressions were analyzed by western blotting. Each bar represents the mean \pm SEM of three independent observations.

‘*'represents statistical significance between control versus DADS treatment groups at $p<0.05$ level using Student's-Newman-Keul's test. L1-control; L2-20 $\mu \mathrm{M}$ DADS; L3- $40 \mu \mathrm{M}$ DADS

Figure 7: Effect of DADS on IKK, IKK, NFKB protein expression in PC-3 cells.

\section{Effect of DADS on IKKa, IKK $\beta$ and NFKB expression in PC3 cells}

NFkB activation is regulated by AKT signaling pathway. DADS significantly decreased IKKa, IKK $\beta$ and NFkB expression thereby inhibited the AKT and NFKB mediated cell survival (Figure 7).

\section{Effect of nimbolide on protein levels of PI3K and pAkt}

Protein levels of PI3K and pAkt were assessed by western blot analysis. PI3K are intracellular signaling molecules of IGF pathways. PI3K are central regulator of Akt phosphorylation. The present study showed that PI3K protein expression decreased after nimbolide treatment in both the breast cancer cells (Figure 8). Akt is a cell survival protein. PAkt is constitutively expressed in breast cancer cells. This combined treatment also inhibits the phosphorylation of Akt. But, the total Akt level remains unchanged. So, the pAkt was normalized with total Akt (Figure 9). Nimbolide inhibits the Akt phosphorylation in MCF-7 and MDA-MB-231 cells. From the above results, it is proved that nimbolide potentially decreased the pAkt expression and leads to inhibition of cell proliferation and survival (Figure 9).

\section{Effect of nimbolide on IKKa, IKK $\beta$ and NFkB expression in breast cancer cell lines}

The IKKa and IKK $\beta$ enzyme complex is part of the upstream NFKB signal transduction cascade. $\mathrm{NF \kappa B}$ is an important transcription factor involved in cell survival. Nimbolide $(2,4 \mu \mathrm{M}$ concentrations in MCF7 cells and 4,6 $\mu \mathrm{M}$ in MDA-MB-231 cells) significantly decreased the protein expressions of IKKa, IKK $\beta$, and NFKB in both the cell lines (Figure 10).

\section{Discussion}

Previous studies showed that quercetin/ DADS suppressed the proliferation of prostate cancer cells [15,16,22-24] through cell cycle arrest and apoptosis. Cancer cells escape normal biochemical systems regulating the balance between apoptosis and survival. PC-3 cells were treated with different concentrations of quercetin/DADS. The cell viability was significantly decreased in $50 \%$ at $100 \mu \mathrm{M}$ quercetin and 40 $\mu \mathrm{M}$ concentration of DADS. So we selected 50 and $100 \mu \mathrm{M}$ concentration of quercetin/20 and $40 \mu \mathrm{M}$ of DADS for the present study. 


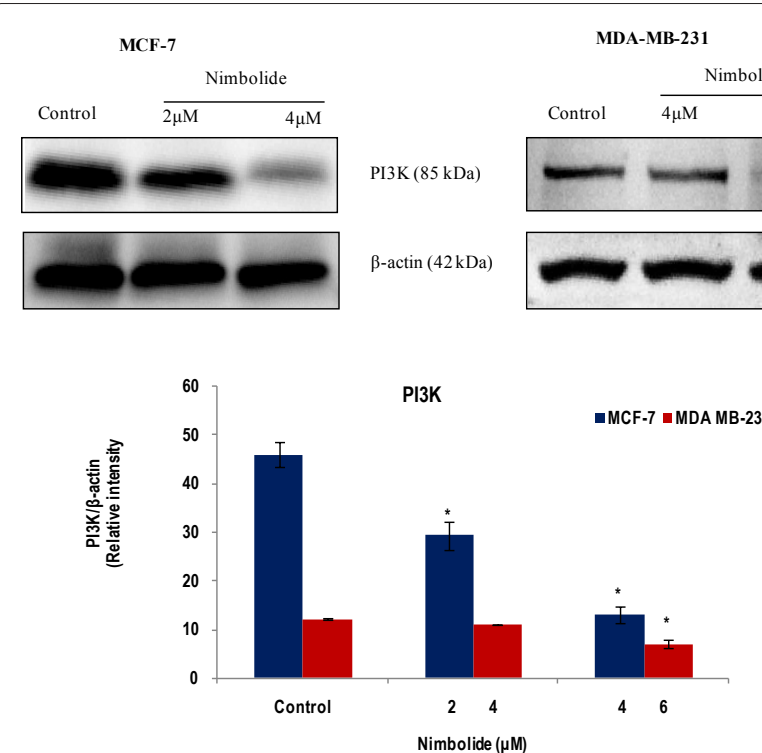

Each bar represents mean + SEM of three independent observations. '*' represents statistical significance between control versus nimbolide treatment groups at $p<0.05$ level using Student's-Newman-Keul's test

Figure 8: Effect of nimbolide on PI3K protein expressions in MCF-7 and MDAMB-231 cell lines.

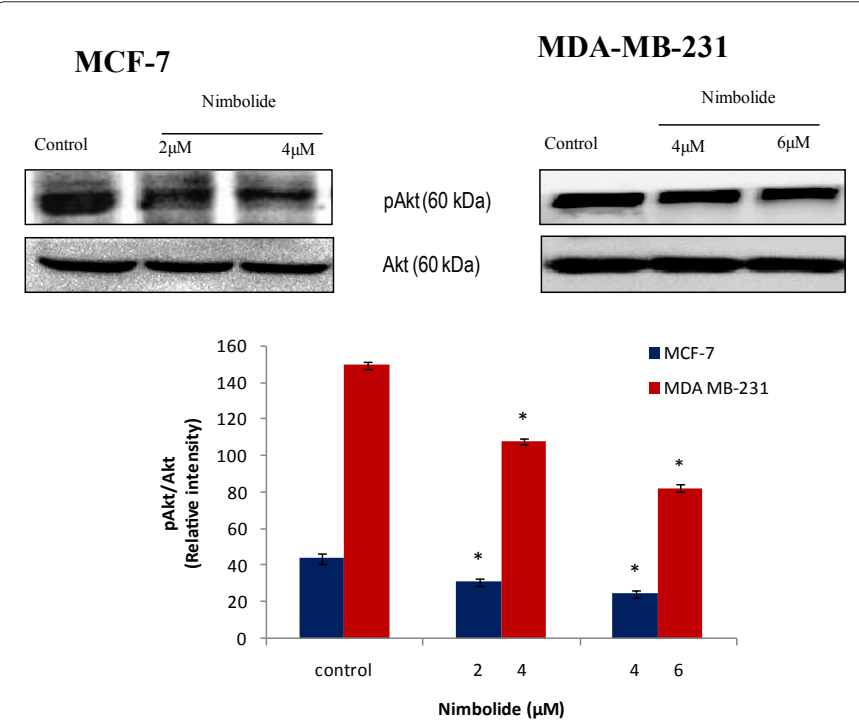

Each bar represents mean + SEM of three independent observations.

“*'represents statistical significance between control versus nimbolide treatment groups at $p<0.05$ level using Student's-Newman-Keul's test

Figure 9: Effect of nimbolide on pAkt protein expression in MCF-7 and MDAMB-231 cell lines.

Sastry et al. [25] tested the in vitro cytotoxicity of nimbolide against a panel of human cancer cell lines and reported IC50 values of that ranged from $4.17 \mu \mathrm{m}$ to $15.56 \mu \mathrm{m}$ with an average of $8.31 \mu \mathrm{m}$. Roy et al. [26] investigated the inihibitory effect of nimbolide on the growth of HL 60, U937 and THP 1-leukemic cells and melanoma B16 cell lines. Harish kumar et al. [27] worked on BeWo cells. Kavitha et al. [20] worked on HepG2 cells. However, so far no study has reported the cytotoxicity effect of nimbolide on breast cancer cell lines. Therefore, we investigated the cytotoxic effect of nimbolide on breast cancer cell in a dose and time dependent manner. In the present study, nimbolide exerted cytotoxic effects on MCF-7 cells with $\mathrm{IC}_{50}$ values of $4.0 \mu \mathrm{M}$ and $2.7 \mu \mathrm{M}$ for 24 and $48 \mathrm{~h}$, respectively. Nimbolide could induce cytotoxicity not only in MCF-7 cells but also in MDA-MB-231 cells with $\mathrm{IC}_{50}$ values of $6.0 \mu \mathrm{M}$ and $3.2 \mu \mathrm{M}$ for 24 and $48 \mathrm{~h}$, respectively. However, MCF 7 cell were more sensitive than the MDA-MB-231 cells. The activation of NFkB typically occurs through site specific phosphorylation and subsequent degradation of I $\kappa$ B.

PI3K/Akt survival pathway is constitutively up regulated either due to the loss of function and/or mutations of the tumor suppressor PTEN, which functions as a negative regulator of PI3K through its lipid phosphatase activity [28]. In particular, PTEN dephosphorylates the D3 position of the key lipid second messenger phosphotidyl inositol 3,4,5-triphosphate (PIP3) $[28,29]$. Our results showed that the protein expression pAkt was significantly decreased in nimbolide treated cells. The protein expression of PI3K, an up-stream regulator of Akt, was also significantly decreased upon nimbolide treatment in both MCF-7 and MDA-MB-231 cell lines.

Anti-proliferative effects of PI3K are due to its activation of serine/ threonine protein kinase Akt. Quercetin inhibits Akt phosphorylation. Previous reports also support the present study that quercetin decreased phosphorylation of Akt and expression of survive in prostate cancer cells $[30,31]$. Decrease in PI3K levels is also one of the reasons for decreased pAkt. In the present study PI3K expression significantly decreased after quercetin treatment. This argument is supported by previous studies showed that quercetin is an inhibitor of PI3K [32]. PI3K-Akt and its associated regulatory signaling pathways are potential targets for therapeutic intervention and molecular based approaches for management of prostate cancer in humans. By suppressing the activation of Akt-1, quercetin can promote apoptosis via several pathways. Thus, quercetin is a potent inhibitor of PI3K/Akt pathway.

Prostate cancer specifically shows biochemical abnormalities related to Akt that may be important in sustaining tumor growth by preventing apoptosis and promoting proliferation and angiogenesis [33]. Akt over expression has been demonstrated in prostate cancer [34]. Complete activation of the catalytic activity of Akt requires phosphorylation of a threonine residue at 308 and a serine residue at 473 . It is possible that Akt shows par-tial activation with phosphorylation at the threonine 308 position [35]. Hence, phosphorylation at ser 473 is the key for the complete activation of Akt. In the present study, DADS significantly decreased the expression of pAkt in PC-3 cells at $40 \mu \mathrm{M}$ concentration and also caused a significant decrease in the expression of ser 473 phosphorylated Akt. This is supported by the study conducted by Xiao et al. [36], in which treatment with diallyl trisulfide, a constituent of processed garlic mediated Akt inactivation and dephosphorylation of Bad and its mitochondrial translocation resulting in apoptosis. In the present study, since there is a decreased expression of AKT phosphorylation due to DADS treatment, there is also activation of pro-apoptotic proteins Bad and Bax which will finally lead to apoptosis in prostate cancer cells. Thus apoptotic effects of DADS are mediated through inhibition of Akt phosphorylation.

The activation of NFkB typically occurs through site specific phosphorylation and subsequent degradation of IKB. This allows the translocation of $N F \kappa B$ into the nucleus to bind the NFKB -specific DNA-binding sites and regulates gene transcription. $\mathrm{NFKB}$ activation is regulated by Akt-signalling pathway [37]. NFKB plays an important role in the apoptotic process [38]. Major target of Akt is the NFkB pathway.

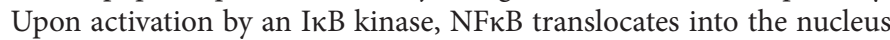
where it regulates gene expression. Many of its target genes have antiapoptotic effects, such as Bcl-2, or regulate the cell cycle, such as c-Myc 

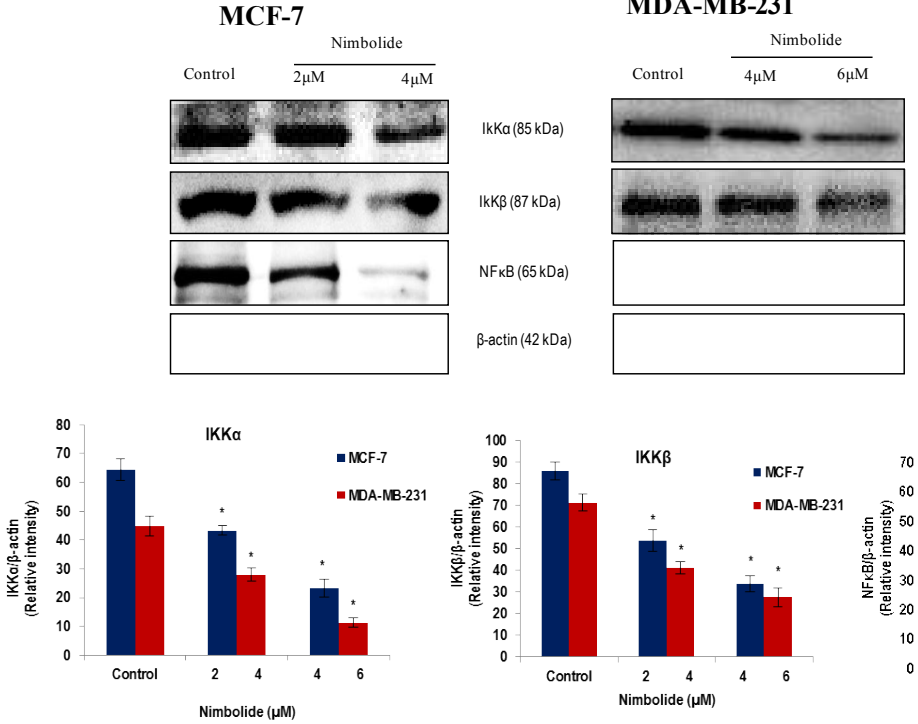

\section{MDA-MB-231}

Nimbolide $(\mu \mathrm{N})$

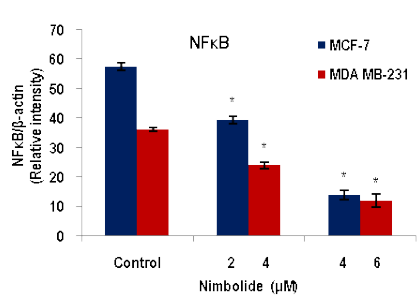

Each bar represents mean + SEM of three independent observations.

“'represents statistical significance between control versus nimbolide treatment groups at $p<0.05$ level using Student's-Newman-Keul's test

Figure 10: Effects of nimbolide on the protein expressions of IkKa, IkK and NFKB in breast cancer cell lines.

and cyclin D1. Inhibition of NFkB by other anticancer drug has been observed in prostate cancer, breast cancer and other cancers [39]. In the present study DADS inhibits NFKB, IKKa and IKK $\beta$ protein expression in prostate cancer cells. Quercetin did the same. In breast cancer cells also nimbolide inhibits NFKB, IKKa and IKK $\beta$ protein expression.

NFkB a major target of Akt, which regulates various cellular process which leads to cancer cells progression. Thus, the present study proves that treatment with quercetin/DADS/nimbolide inhibited the NFкB mediated proliferation and survival of prostate and breast cancer cells. Our results suggest that quercetin/DADS/nimbolide may be a potential therapeutic agent for prostate and breast cancer in future. Further in vitro and in vivo studies on the molecular mechanism are warranted.

\section{Acknowledgement}

Financial assistance by DBT, CSIR, DST-PURSE and Government of India is greatly acknowledged.

\section{References}

1. Ting AT, Pimentel-Muinos FX, Seed B (1996) RIP mediates tumor necrosis factor receptor 1 activation of NF-kappaB but not Fas/APO-1-initiated apoptosis. EMBO J 15: 6189-6196.

2. Reynaert NL, Ckless K, Korn SH, Vos N, Guala AS, et al. (2004) Nitric oxide represses inhibitory kappaB kinase through S-nitrosylation. Proc Natl Acad Sci U S A 101: 8945-8950.

3. Pandey MK, Sung B, Ahn KS, Kunnumakkara AB, Chaturvedi MM, et al. (2007) Gambogic acid, a novel ligand for transferrin receptor, potentiates TNF-induced apoptosis through modulation of the nuclear factor-kappaB signaling pathway. Blood 110: 3517-3525.

4. Ha KH, Byun MS, Choi J, Jeong J, Lee KJ, et al. (2009) N-tosyl-L-phenylalanine chloromethyl ketone inhibits NF-kappaB activation by blocking specific cysteine residues of IkappaB kinase beta and p65/RelA. Biochemistry 48: 7271-7278.

5. Vanhaesebroeck B, Waterfield MD (1999) Signaling by distinct classes of phosphoinositide 3-kinases. Exp Cell Res 253: 239-254.

6. Vivanco I, Sawyers CL (2002) The phosphatidylinositol 3-Kinase AKT pathway in human cancer. Nat Rev Cancer 2: 489-501.

7. Kandel ES, Skeen J, Majewski N, Di Cristofano A, Pandolfi PP, et al. (2002)
Activation of Akt/protein kinase B overcomes a $\mathrm{G}(2) / \mathrm{m}$ cell cycle checkpoint induced by DNA damage. Mol Cell Biol 22: 7831-7841.

8. Kandel ES, Hay N (1999) The regulation and activities of the multifunctional serine/threonine kinase Akt/PKB. Exp Cell Res 253: 210-229.

9. Choi JA, Kim JY, Lee JY, Kang CM, Kwon HJ, et al. (2001) Induction of cell cycle arrest and apoptosis in human breast cancer cells by quercetin. Int $J$ Oncol 19: 837-844.

10. Kuo PC, Liu HF, Chao JI (2004) Survivin and p53 modulate quercetin-induced cell growth inhibition and apoptosis in human lung carcinoma cells. J Biol Chem 279: 55875-55885

11. Ong CS, Tran E, Nguyen TT, Ong CK, Lee SK, et al. (2004) Quercetininduced growth inhibition and cell death in nasopharyngeal carcinoma cells are associated with increase in Bad and hypophosphorylated retinoblastoma expressions. Oncol Rep 11: 727-733.

12. Vijayababu MR, Arunkumar A, Kanagaraj P, Arunakaran J (2006) Effects of quercetin on insulin-like growth factors (IGFs) and their binding protein-3 (IGFBP-3) secretion and induction of apoptosis in human prostate cancer cells. J Carcinog 5: 10

13. Choi EJ, Bae SM, Ahn WS (2008) Antiproliferative effects of quercetin through cell cycle arrest and apoptosis in human breast cancer MDA-MB-453 cells. Arch Pharm Res 31: 1281-1285.

14. Jung YH, Heo J, Lee YJ, Kwon TK, Kim YH (2010) Quercetin enhances TRAILinduced apoptosis in prostate cancer cells via increased protein stability of death receptor 5. Life Sci 86: 351-357.

15. Senthilkumar K, Elumalai P, Arunkumar R, Banudevi S, Gunadharini ND, et al. (2010) Quercetin regulates insulin like growth factor signaling and induces intrinsic and extrinsic pathway mediated apoptosis in androgen independent prostate cancer cells (PC-3). Mol Cell Biochem 344: 173-184

16. Senthilkumar K, Arunkumar R, Elumalai P, Sharmila G, Gunadharini DN, et al. (2011) Quercetin inhibits invasion, migration and signalling molecules involved in cell survival and proliferation of prostate cancer cell line (PC-3). Cell Biochem Funct 29: 87-95.

17. Yi L, Su Q (2013) Molecular mechanisms for the anti-cancer effects of diallyl disulfide. Food Chem Toxicol 57: 362-370.

18. Gupta SC, Reuter S, Phromnoi K, Park B, Hema PS, et al. (2011) Nimbolide sensitizes human colon cancer cells to TRAIL through reactive oxygen speciesand ERK-dependent up-regulation of death receptors, p53, and Bax. J Bio Chem 286: 1134-1146.

19. Babykutty S, S PP, J NR, Kumar MA, Nair MS, et al. (2012) Nimbolide retards 
Citation: Arunakaran J, Arunkumar R, Elumalai P, Senthilkumar K (2013) Impact of Quercetin, Diallyl Disulfide and Nimbolide on the Regulation of Nuclear Factor Kappa B Expression in Prostate and Breast Cancer Cell Lines. Nat Prod Chem Res 1: 115 doi:10.4172/ 2329-6836.1000115

Page 7 of 7

tumor cell migration, invasion, and angiogenesis by downregulating MMP-2/9 expression via inhibiting ERK1/2 and reducing DNA-binding activity of NF- $\mathrm{B}$ in colon cancer cells. Mol Carcinog 51: 475-490.

20. Kavitha K, Vidya Priyadarsini R, Anitha P, Ramalingam K, Sakthivel R, et al. (2012) Nimbolide, a neem limonoid abrogates canonical NF-kB and Wnt signaling to induce caspase-dependent apoptosis in human hepatocarcinoma (HepG2) cells. Eur J Pharmacol 681: 6-14.

21. Lowry OH, Rosebrough NJ, Farr AL, Randall RJ (1951) Protein measurement with the Folin phenol reagent. J Biol Chem 193: 265-275.

22. Arunkumar A, Vijayababu MR, Srinivasan N, Aruldhas MM, Arunakaran $J$ (2006) Garlic compound, diallyl disulfide induces cell cycle arrest in prostate cancer cell line PC-3. Mol Cell Biochem 288: 107-113.

23. Gayathri R, Gunadharini DN, Arunkumar A, Senthilkumar K, Krishnamoorthy $\mathrm{G}$, et al. (2009) Effects of diallyl disulfide (DADS) on expression of apoptosis associated proteins in androgen independent human prostate cancer cells (PC3). Mol Cell Biochem 320: 197-203.

24. Arunkumar R, Sharmila G, Elumalai P, Senthilkumar K, Banudevi S, et al. (2012) Effect of diallyl disulfide on insulin-like growth factor signaling molecules involved in cell survival and proliferation of human prostate cancer cells in vitro and in silico approach through docking analysis. Phytomedicine 19: 912-923.

25. Sastry BS, Suresh Babu K, Hari Babu T, Chandrasekhar S, Srinivas PV, et al. (2006) Synthesis and biological activity of amide derivatives of nimbolide. Bioorg Med Chem Lett 16: 4391-4394.

26. Roy MK, Kobori M, Takenaka M, Nakahara K, Shinmoto H, et al. (2007) Antiproliferative effect on human cancer cell lines after treatment with nimbolide extracted from an edible part of the neem tree (Azadirachta indica). Phytother Res 21: 245-250.

27. Harish Kumar G, Chandra Mohan KV, Jagannadha Rao A, Nagini S (2009) Nimbolide a limonoid from Azadirachta indica inhibits proliferation and induces apoptosis of human choriocarcinoma (BeWo) cells. Invest New Drugs 27: 246252.

28. Noh EM, Lee YR, Chay KO, Chung EY, Jung SH, et al. (2011) Estrogen receptor ainduces down-regulation of PTEN through PI3-kinase activation in breast cancer cells. Mol Med Rep 4: 215-219.

29. Stambolic V, Suzuki A, de la Pompa JL, Brothers GM, Mirtsos C, et al. (1998) Negative regulation of $\mathrm{PKB} / \mathrm{Akt}-$ dependent cell survival by the tumor suppresso PTEN. Cell 95: 29-39.

30. Kim YH, Lee YJ (2007) TRAIL apoptosis is enhanced by quercetin through Akt dephosphorylation. J Cell Biochem 100: 998-1009.

31. Kim YH, Lee DH, Jeong JH, Guo ZS, Lee YJ (2008) Quercetin augments TRAIL-induced apoptotic death: involvement of the ERK signal transduction pathway. Biochem Pharmacol 75: 1946-1958.

32. Gamet-Payrastre L, Manenti S, Gratacap MP, Tulliez J, Chap H, et al. (1999) Flavonoids and the inhibition of PKC and PI 3-kinase. Gen Pharmacol 32: 279286.

33. Nelson ED, Slotoroff CB, Gomella LG, Halpern EJ (2007) Targeted biopsy of the prostate: the impact of color Doppler imaging and elastography on prostate cancer detection and Gleason score. Urology 70: 1136-1140.

34. Edwards J, Krishna NS, Witton CJ, Bartlett JM (2003) Gene amplifications associated with the development of hormone-resistant prostate cancer. Clin Cancer Res 9: 5271-5281.

35. Nicholson KM, Anderson NG (2002) The protein kinase B/Akt signalling pathway in human malignancy. Cell Signal 14: 381-395.

36. Xiao D, Lew KL, Kim YA, Zeng Y, Hahm ER, et al. (2006) Diallyl trisulfide suppresses growth of PC-3 human prostate cancer xenograft in vivo in association with Bax and Bak induction. Clin Cancer Res 12: 6836-6843.

37. Ozes ON, Mayo LD, Gustin JA, Pfeffer SR, Pfeffer LM, et al. (1999) NF-kappaB activation by tumour necrosis factor requires the Akt serine-threonine kinase. Nature 401: 82-85.

38. Romashkova JA, Makarov SS (1999) NF-kappaB is a target of AKT in antiapoptotic PDGF signalling. Nature 401: 86-90.

39. Pavese JM, Farmer RL, Bergan RC (2010) Inhibition of cancer cell invasion and metastasis by genistein. Cancer Metastasis Rev 29: 465-482. 